\title{
The European Geotraverse Project: a major European scientific venture
}

\author{
R. Freeman and St. Mueller, Zurich
}

(University of Zurich)

\section{Part I}

The Rhine River is not only one of western Europe's chief political and historical landmarks, the valley through which it flows is also a major geological feature. About 40 million years ago, the crust (the top 25-30 km of the Earth's lithosphere) of Europe began to split apart creating the rift valley through which the Rhine presently flows. France and the Federal Republic of Germany are still neighbours today because of events occurring several thousand kilometres distant. The South Atlantic is widening at a faster rate $(41 \mathrm{~mm} / \mathrm{y})$ than the North Atlantic $(18 \mathrm{~mm} / \mathrm{y})$ which causes Africa to rotate counterclockwise and push northwards against central Europe. This movement of Africa relative to Europe determines the nearly north-south orientation of tectonic stress in Europe which hinders further rifting of the continent along the upper Rhine valley but induces rifting in the lower Rhine valley and causes the Alps to rise at the rate of roughly $1 \mathrm{~mm} / \mathrm{y}$. How continents are rifted apart and built up are major research themes in the earth sciences. The European Geotraverse (EGT) is a multinational, interdisciplinary project designed to coordinate European research into these fundamental problems through a series of experiments along a particular cross-section of the Earth's lithosphere.

The theory of plate tectonics has unified in one elegant framework many long-standing questions and diverse observations on problems of earth dynamics. In this new global view, the present morphology of the Earth's surface was created by the dynamic interaction of several large lithospheric plates which move over the surface of the Earth and upon which the oceans and continents

Table I: EGT Data Compilations

\begin{tabular}{|c|c|c|c|}
\hline type & property measured & interpretation method & application \\
\hline aeromagnetic & $B_{\text {tot }}$ & potential theory & $\begin{array}{l}\text { magnetic anomalies, } \\
\text { depth to basement }\end{array}$ \\
\hline $\begin{array}{l}\text { geoelectric, } \\
\text { magnetotelluric, and } \\
\text { magnetometer arrays }\end{array}$ & $\begin{array}{l}\text { apparent resistivity } \\
\mathrm{E}_{x}, \mathrm{E}_{\mathrm{y}}, \mathrm{B}_{x}, \mathrm{~B}_{y}, \mathrm{~B}_{z} \\
\mathrm{~B}_{x}(\mathrm{t}), \mathrm{B}_{y}(\mathrm{t}), \mathrm{B}_{z}(\mathrm{t})\end{array}$ & $\begin{array}{l}\text { potential fields } \\
\text { potential fields } \\
\text { potential fields }\end{array}$ & $\begin{array}{l}\text { resistivityldepth } \\
\text { resistivityldepth } \\
\text { resistivityldepth }\end{array}$ \\
\hline $\begin{array}{c}\text { Surface-wave } \\
\text { dispersion }\end{array}$ & $\begin{array}{l}3 \text { component distant } \\
\text { earthquake records }\end{array}$ & dispersion analysis & $\begin{array}{l}\text { density structure } \\
\text { of mantle }\end{array}$ \\
\hline P-wave delay & $\begin{array}{l}1.3 \text { component near } \\
\text { and or distant records }\end{array}$ & seismic tomography & $\begin{array}{l}\text { seismic velocity } \\
\text { with depth }\end{array}$ \\
\hline $\begin{array}{l}\text { reflection and } \\
\text { refraction seismics }\end{array}$ & elastic waves & $\begin{array}{r}\text { digital signal } \\
\text { processing }\end{array}$ & $\begin{array}{l}\text { depth and seismic } \\
\text { velocity of subsurface }\end{array}$ \\
\hline $\begin{array}{l}\text { seismicity and } \\
\text { seismotectonics }\end{array}$ & earthquake records & $\begin{array}{l}\text { focal mechanism } \\
\text { solutions }\end{array}$ & $\begin{array}{l}\text { present day stress } \\
\text { fields }\end{array}$ \\
\hline gravity & $\begin{array}{c}\text { acceleration of } \\
\text { gravity }(\Delta g)\end{array}$ & $\begin{array}{l}\text { elevation, tidal, and, } \\
\text { density corrections }\end{array}$ & density anomalies \\
\hline $\begin{array}{l}\text { recent crustal } \\
\text { movements }\end{array}$ & $\Delta \mathrm{x}, \Delta \mathrm{h}$ & precise leveling & $\begin{array}{l}\text { dynamic tectonics, } \\
\text { isostasy }\end{array}$ \\
\hline geothermics & $\begin{array}{l}\text { temperature, } \\
\text { heat flow }\end{array}$ & heat flow equation & $\begin{array}{l}\text { magmatic activity, } \\
\text { radioactive elements }\end{array}$ \\
\hline geochronology & $\begin{array}{l}\text { radionuclide isotope } \\
\text { concentration }\end{array}$ & mass spectrometry & age dating \\
\hline geochemistry & $\begin{array}{l}\text { elemental } \\
\text { composition }\end{array}$ & $\begin{array}{l}\text { various analytical } \\
\text { techniques }\end{array}$ & tectonic environments \\
\hline geological & $\begin{array}{l}\text { rock types and } \\
\text { structure }\end{array}$ & field mapping & $\begin{array}{l}\text { direct record of crustal } \\
\text { features at surface }\end{array}$ \\
\hline palaeomagnetic & $\begin{array}{l}\mathrm{B}_{x}, \mathrm{~B}_{y}, \mathrm{~B}_{2} \\
\text { in rock samples }\end{array}$ & $\begin{array}{l}\text { thermal and alternating } \\
\text { field demagnetization }\end{array}$ & $\begin{array}{l}\Delta \text { declination, } \\
\Delta \text { inclination }\end{array}$ \\
\hline
\end{tabular}

passively ride. The lithosphere is the outermost $50-150 \mathrm{~km}$ of the Earth, of which only the uppermost surface is accessible for direct study. A distinct seismic boundary divides the lithosphere into crust and upper mantle. Designated the "Moho" after Andrija Mohorovicic, a Croatian seismologist who first noted this feature at the beginning of the twentieth century, this discontinuity has been found to occur at depths ranging from $3-5 \mathrm{~km}$ (under the ocean floor) to $50-70 \mathrm{~km}$ (beneath mountain ranges, such as the Alps and Himalayas).

Below the relatively cold and rigid lithosphere is a hotter and more ductile layer of the upper mantle called the "asthenosphere". Although not liquid, the asthenosphere is capable of slow movement. It is a solid which deforms under stress, like ice that is brittle if suddenly hit yet is able to "flow" in the form of a glacier.

One popular model proposes huge thermal convection cells within the mantle to drive the motion of the plates. Where material from the cells rises to the surface, continents are rifted apart and oceans are created. Where material descends, one or both of the two converging lithospheric plates plunges back into the mantle. Denser (usually oceanic) material tends to be subducted under less dense (usually continental) material, and the relatively light sedimentrary skin of the oceanic layer gets scraped off and "plastered" or accreted to the edge of the lithosphere carrying the continent. But what happens when continental material riding on one slab collides with continental material of similar density on the other slab? Since neither can easily by subducted under the other, mountain belts are formed by collision as evidenced by the Alps and the Himalayas. Besides growth by accretion of oceanic and continental material, land masses can be enlarged by intrusion of magmas into the overlying lithosphere as parts of the downgoing slab melt, and also by extrusion of basalts in mid-continental rifts such as the one that formed the Rhine valley. Although this model presented by plate tectonics offers a self-consistent global picture, 


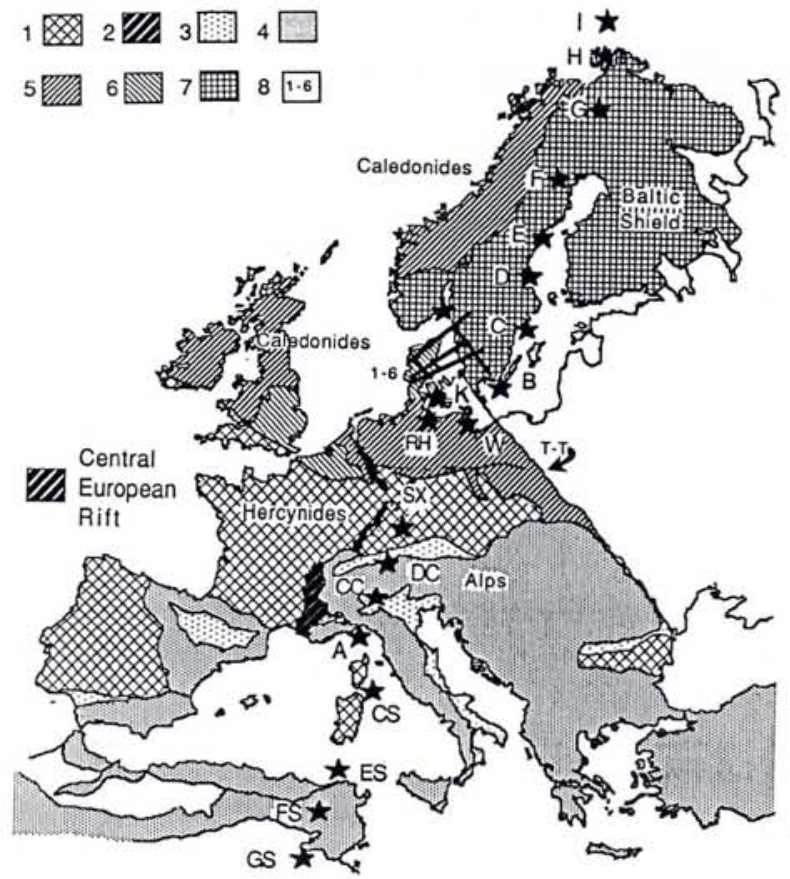

Fig. 1 - The EGT: a $4000 \mathrm{~km}$ north-south profile from the North Cape to the Sahara. Stars represent shotpoints of major refraction seismic surveys: shotpoints I-F are from the FENNOLORA experiment, lines 1-6 are from the EUGENO-S experiment (both northern segment); K-DC-CC-A from the EUGEMI (central segment); A-GS from the two EGT-S experiments (southern segment). $R H=$ Rhenohercynian zone; $S X=$ Saxothuringian zone. Patterns indicate major tectonic provinces and features; 1: Hercynides, 2: Central European Rift, 3: Cenozoic basins, 4: Alps, 5: Caledonides, 6: platforms of uncertain age, 7: Baltic Shield, 8: EUGENO-S seismic profiles. T-T: Teisseyre-Tornquist line.

most existing theories developed to explain details of the dynamics and kinematics of these processes raise serious questions.

\section{Organisation of the EGT Project}

The EGT Project was created to collect key data to help quantify and improve some of these models as they relate to the deep structure of the continents which is older and more complex than the oceanic lithosphere. It includes the widest range of continental building processes - in both age and style that can be found on the Earth along one uninterrupted stretch. The geologic provinces through which the EGT passes tell a story of repeated cycles of extension (rifting and ocean formation) and compression (subduction and accretion). From north to south, the $4000 \mathrm{~km}$ traverse (Fig. 1) originates in the ancient (3600-600 Ma) rocks of the Baltic Shield and terminates in the eastern Sahara of Tunisia.

The idea of a large project evolved in 1980 , based on experience gained during the international seismic refraction experiment "FENNOLORA" (Fennoscandian Long-Range Project) conducted in 1979. Subsequently a Working Group composed of scientists and administrators nominated by the participating organisations from 16 countries was set up by the European Science Research
Councils (ESRC), a standing committee of the European Science Foundation (ESF), to invite, evaluate, and select proposals for specific experiments and to integrate these into a coherent programme. The resulting "Joint Programme" of 12 (subsequently 13 ) major projects and numerous geographically more limited projects under the heading of "Regional Studies" was proposed to and approved by the General Assembly of the ESF in November 1982 under the framework of the European Geotraverse. The EGT has since turned out to be one of the most successful international and interdisciplinary endeavours of this decade.

The ESRC Working Group set up a 10 member Scientific Coordinating Committee (SCC) which oversees and coordinates the scientific organisation of the Joint Programme. The ESF finances the activities of the SCC whereas the projects comprising the Joint Programme are funded on a cost-sharing basis either directly by the member organisations, by appropriate national agencies, or through European Community resources, on the basis of research proposals. cording to the specific practices of each agency or organisation. For logistic reasons the EGT was divided into a northern, central, and southern segment. The detailed activities in each segment These are submitted and reviewed ac- are delegated to three sectional subgroups, each with a general coordinator and a scientific assistant.

Earth scientists from 14 nations have been involved in the 13 projects of the EGT Joint Programme. As of Spring $1987,70 \%$ of the major programmes have been carried out, each one pooling manpower (up to 150 participants) from 11 European institutions. Over the next three years, the analysis of the incoming data and the compilation of existing geophysical data (see Table I) will contribute to knowledge of the lithosphere beneath Europe and to research into the fundamental processes of continental building.

In order to inventory existing data, facilitate international collaboration and ameliorate integration of different types of geophysical and geological data, three kinds of scientific meetings have been organised: three-week long, intensive studies within the ESF's Earth Science Network, of which two have been held to date; a series of 3-day workshops designed to review what is known about each of the three segments (the proceedings are available free of charge from the ESF in Strasbourg); symposia comprising individual status and progress reports at international meetings. Moreover there are informal meetings of working groups that are compiling, analysing, and interpreting data. Two special issues of Tectonophysics have appeared as well as various reports in other scientific journals.

\section{METHODS}

Trying to understand the formation of continents from the surface is akin to an ant on the back of an elephant trying to understand how his host moves with only his vibration-sensitive limbs as probes. Only a very thin "skin" - the outermost layers of the Earth - is accessible to direct study by earth scientists. There are nevertheless surficial exposures of rocks whose composition and texture imply that they were at one time in the range of temperatures and pressures which characterise conditions in the lower crust and upper mantle, for instance, in the Ivrea Zone of northern Italy. Fragments of deep-seated material found in basalts heaved up to the surface in kimberlite pipes and volcanoes evidence an origin tens of kilometres beneath the Earth's surface. In addition to costly deep drilling, these two research areas (metamorphic petrology and xenolith geochemistry) are examples of the few available "direct" methods. However, the rock samples represent a very limited and probably atypical 
$\mathrm{N}$

Caledonides

Baltic Shield

European Platform

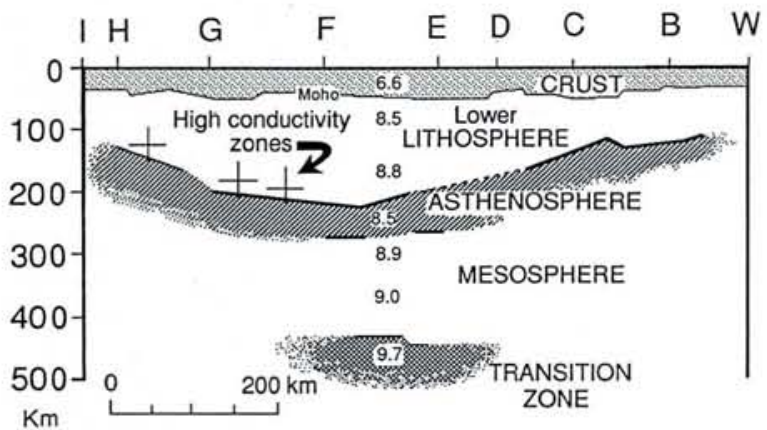

Fig. 2 - Cross-section through the crust and upper mantle from the North Cape to European platform based on results of the FENNOLORA Project. The divisions into crust and upper mantle (lithosphere), asthenosphere and mesosphere were determined by seismic velocities (6.6-9.7) expressed in $\mathrm{km} / \mathrm{s}$ (model and data from Ref. 1). Large crosses identify zones of high conductivity (data from Refs. 3 and 6).

part of the lithosphere and are found today in an environment far from their origin. In contrast, there are indirect methods which aim to acquire data on the present state of rocks deep in the lithosphere. From the variety of methods which are incorporated into the EGT Project (see Table I) we shall discuss three that form the backbone of the Project's experimental structure: seismic profiles, electromagnetic surveys, and gravimetric measurements.

\section{Seismic Methods}

Studying the records of elastic, or seismic waves is one of the major ways of gaining information on the deeper layers of the Earth. In terms of manpower, organisation of field experiments, and funding money, acquisition of seismic data is the most intensive aspect of the EGT Project. Elastic waves generated by earthquakes or large explosions travel into the Earth and are reflected back at interfaces of velocity and/or density (i.e. impedance) changes, just as a rock cliff will echo back acoustic waves. Like our ear picking up sounds, instruments called geophones sensitive to very small ground motions register these echoes of distant earthquakes or large explosions as they return to the surface. As the waves travel through layers of rock, they are attenuated, sped up, slowed down, and partially reflected back to the surface. The arrival times after reflection are diagnostic for the velocity and/or density of the material through which the waves travel and the depths to interfaces of impedance changes. Seismic experiments are usually termed reflection, when the ray paths are nearly vertical (source to receiver distance small compared with depth to reflecting layer), or refraction, when the ray paths are largely horizontal (source to receiver distance large compared with depth to refracting interface). Reflection seismics yields good resolution of the geologic structure whereas refraction seismics gives better resolution of impedance and depth data.
There are two kinds of elastic waves: body waves which travel through the Earth, and surface waves which travel in a complex fashion along the surface. These latter cause the most damage in earthquakes. Body waves can be either compressional (also called P-waves) with particle movement in the direction of wave propagation, or shear (also called S-waves) with particle movement perpendicular to the direction of wave propagation. Depending upon the elastic parameters at each reflecting interface, both S- and P-waves can be produced from incoming $\mathrm{P}$ - and $\mathrm{S}$-waves. This property coupled with the heterogeneity of the real Earth and non-ideal source signals result in an extremely complex wave train received at the surface. Thus empirical methods with gross simplifications are usually necessary to construct initial models. Due to the large quantity of data and complex calculations, digital processing of seismic signals in petroleum exploration and academic research is one of the world's major consumers of computer time and magnetic tapes.

In spite of these difficulties, seismics offers one of the most powerful methods of elucidating the structure of the Earth. Besides being the conceptual and experimental forerunner to the EGT, the 1979 FENNOLORA large-scale refraction seismic experiment demonstrates the potential results of this method. One of the several spectacular products of this $2000 \mathrm{~km}$ long refraction seismic profile across Scandinavia is a clear definition of the structure in the lithosphere and upper mantle down to a depth of $440 \mathrm{~km}$. Fig. 2 shows the evidence for a thickening of the lithosphere from underneath shotpoint $\mathrm{W}$ in Pomerania (Baltic coast, German Democratic Republic) to below shotpoint $F$ in northern Sweden. Detailed analysis of the seismic results ${ }^{1}$ ) shows zones of vertically alternating lower and higher seismic velocities between $8.2 \mathrm{~km} / \mathrm{s}$ at $50 \mathrm{~km}$ depth to $8.8 \mathrm{~km} / \mathrm{s}$ at $200 \mathrm{~km}$ depth with widespread lateral heterogeneity (not shown in Fig. 2). This heterogeneous lithospheric "keel" penetrates into a more homogeneous "asthenosphere" marked by a drop in seismic velocities from $8.8 \mathrm{~km} / \mathrm{s}$ to $8.4-8.5 \mathrm{~km} / \mathrm{s}$. Analysis of the dispersion of seismic surface waves shows that this low velocity layer has a lower density than the overlying lithosphere and rises rapidly under the northern edge of the Baltic Shield. A prominent reflector at about $440 \mathrm{~km}$ is recognised from many seismic results all over the globe as an important transition layer. Whereas the crust/mantle boundary (the Moho) is due to a change in mineral chemistry, the transition at 440 $\mathrm{km}$ depth is most likely due to a phase transition of the mineral olivine, $(\mathrm{Mg}, \mathrm{Fe})_{2} \mathrm{SiO}_{4}$, the main constituent of the mantle, in which the silicon framework assumes the denser six-fold coordination rather than the usual tetrahedral configuration.

Large-scale refraction seismic experiments like FENNOLORA use man-made sources of chemical explosives that detonate quickly and constitute an artificial point source. Signals from deep reflectors are recorded by portable analog equipment with frequency-multiplex modulation on $1 / 4$ inch magnetic tape. Normally each receiving station requires a field operator to adjust the gain, shoo away cows and reduce (when possible) other sources of unwanted noise, and record the shot. Each recording unit consists of a three-component $2 \mathrm{~Hz}$ universal field seismometer with recorder, amplifier, modulator, and a time signal receiver. The frequency range of the recorded signal is $0.3-100 \mathrm{~Hz}$ with a dynamic range of $60 \mathrm{~dB}$. Digitisation of the original analog data is usually done at playback centres. Evaluation of record sections is through inversion techniques based on travel times of first arrivals of the compressional waves and, when clearly registered, later arrivals of both shear and compressional waves. Amplitude as well as frequency content are used in the analysis by a variety of methods which trace the seismic signal from the shotpoint to the receiver as a ray travelling through mediums with different velocities. The calculated velocity/depth values can then be fed into programmes that compute synthetic seismograms to be compared with the observed results. The end product is a 2 -dimensional profile of the structural layers in terms of depth and seismic velocity such as is shown in Fig. 2.

Further details of the experimental methods used will appear in the next issue of Europhysics News. 